\title{
Evaluation of tissue reaction, cell viability and cytokine production induced by Sealapex Plus
}

\author{
João Eduardo GOMES-FILHO ${ }^{1}$, Alessandra Cristina GOMES², Simone WATANABE², Sandra Helena Penha de \\ OLIVEIRA ${ }^{3}$, Pedro Felício Estrada BERNABÉ ${ }^{4}$, Célio PERCINOTO ${ }^{5}$
}

\begin{abstract}
1- DDS, MSc, PhD, Associate Professor, Department of Endodontics, Araçatuba Dental School, São Paulo State University, Araçatuba, SP, Brazil. 2- DDS, MSc, Postgraduate student in the Department of Pediatric Dentistry, Araçatuba Dental School, São Paulo State University, Araçatuba, SP, Brazil.

3- BMS, MSc, PhD, Associate Professor, Department of Endodontics, Araçatuba Dental School, São Paulo State University, Araçatuba, SP, Brazil. 4- DDS, MSc, PhD, Full Professor, Department of Endodontics, Araçatuba Dental School, São Paulo State University, Araçatuba, SP, Brazil.

5- DDS, MSc, PhD, Full Professor, Department of Pediatric Dentistry, Araçatuba Dental School, São Paulo State University, Araçatuba, SP, Brazil.
\end{abstract}

Corresponding address: Dr. João Eduardo Gomes-Filho - Faculdade de Odontologia de Araçatuba - UNESP - Departamento de Odontologia Restauradora - Endodontia - R. José Bonifácio, 1193 - Araçatuba, SP - Brasil - Phone: +55-18-3636-3252 - Fax: +55-18-3636-3279 - e-mail: joao@foa.unesp.br

Received: August 12, 2009 - Modification: April 06, 2010 - Accepted: April 08, 2010

\section{ABSTRACT}

\begin{abstract}
bjective: The aim of this study was to investigate the effects of mineral trioxide aggregate (MTA), Sealapex, and a combination of Sealapex and MTA (Sealapex Plus) on the reaction of subcutaneous connective tissue of rats, and on cell viability and cytokine production in mouse fibroblasts. Material and Methods: The tissue reaction was carried out with dentin tubes containing the materials implanted in the dorsal connective tissue of rats. The histological analysis was performed after 7 and 30 days. Millipore culture plate inserts with polyethylene tubes filled with materials were placed into 24-well cell culture plates with mouse fibroblasts to evaluate the cell viability by MTT assay. ELISA assays were also performed after $24 \mathrm{~h}$ of exposure of the mouse fibroblasts to set material disks. Results: Histopathologic examination showed Von Kossa-positive granules that were birefringent to polarized light for all the studied materials at the tube openings. No material inhibited the cell viability in the in vitro test. It was detected IL-6 production in all root-end filling materials. MTA and Sealapex Plus induced a slight raise of mean levels of IL-1 $\beta$. Conclusions: The results suggest that Sealapex Plus is biocompatible and stimulates the mineralization of the tissue.
\end{abstract}

Key words: Cytokines. Cultured cells. Dental materials. Biocompatibility testing.

\section{INTRODUCTION}

The ideal material to repair perforations should be biocompatible, seal the root canal system, induce osteogenesis and cementogenesis, and be dimensionally stable, i.e. unaffected by the presence of moisture. In addition, it should be easy to manipulate. Many materials including Cavit IRM, amalgam, Super EBA, composite resins, and glass ionomers have been tested, but none meet all requirements ${ }^{24}$.

Mineral trioxide aggregate (MTA) was introduced to be used in pathologic or iatrogenic root perforations, as well as in root-end cavities ${ }^{12,27}$. Studies have shown that MTA promotes favorable tissue reactions, characterized by absence of severe inflammatory responses, presence of a fibrous capsule, and the induction of formation of mineralized repair tissue and promoted efficient sealing of root perforations ${ }^{2,12}$. The hydrophilic nature of the particles from MTA powder allows its use even in the presence of moisture ${ }^{27}$.

Studies evaluating MTA as a root-end filling material have shown less periapical inflammation, the presence of a fibrous capsule, and the formation of new cementum in contact with the material surface in many cases $^{2}$. Similar findings were reported by Holland, et al. ${ }^{7}$ (2001) in a study with dogs. A dentin bridge covering the pulp tissue was also found after pulp capping with $\mathrm{MTA}^{18}$.

In spite of favorable characteristics, MTA sealer presents working properties that are less than ideal. The resulting cement from the mixing of powder to water is difficult to manipulate ${ }^{25}$; its setting time has 
been reported to be of almost $3 \mathrm{~h}$, while the working time is less than $4 \mathrm{~min}^{14}$. Additional moisture is also required to activate its setting ${ }^{16}$.

Sealapex (Sybron Endo, Glendora, CA, USA) is clinically used due to its favorable healing process, which may be related to the diffusion of ions ${ }^{23}$. This diffusion from the sealer raises the $\mathrm{pH}$ at the surface of the root adjacent to periodontal tissues, and favors the healing ${ }^{28}$. The high $\mathrm{pH}$ favors antimicrobial action ${ }^{4}$, the degradation of bacterial lipopolysaccharides ${ }^{19}$, as well as the induction of hard tissue formation ${ }^{5}$, and the control of inflammatory root resorption ${ }^{30}$.

An experimental combination between Sealapex and MTA (Sealapex Plus) was proposed in order to offer similar biological properties to MTA, but with better working properties, such as handling and working time ${ }^{1}$. Although this experimental combination apparently presents positive characteristics, there is no work evaluating its biocompatibility. There are several methods to evaluate the biocompatibility, but those assessing cytotoxicity and subcutaneous connective tissue response are the most common, standardized and reproducible ones.

The aim of this study was to evaluate the reaction of rat subcutaneous connective tissue to the implantation of dentin tubes filled with a combination of Sealapex ${ }^{\circledR}$ with Angelus ${ }^{\circledR}$ MTA (Angelus, Londrina, Paraná, Brazil) (Sealapex Plus) in comparison to Angelus ${ }^{\circledR}$ MTA and Sealapex ${ }^{\circledR}$. Moreover, the study aimed at determining the effects of the root-end filling materials on cell viability and the expression of inflammatory cytokines using a mouse fibroblasts cell line.

\section{MATERIAL AND METHODS}

\section{Histopathologic study (in vivo test) \\ Animals}

In this study, 24 4-6-month-old male Wistar Albino rats, weighing between 250-280 g, were used. The animals were housed in temperaturecontrolled rooms, and received water and food ad libitum. The care of the animals was carried out according to Research Ethics Committee of Araçatuba School of Dentistry, which approved the project prior to the beginning of the experiments.

\section{Dentin tubes}

Forty-eight dentin tubes were prepared from human tooth roots. The canals were enlarged up to reamer \#35 and then over-instrumented $2 \mathrm{~mm}$ beyond the apical foramen. The length of the tubes was $7 \mathrm{~mm}$, and the thickness of their outer walls about $0.5 \mathrm{~mm}$. The dentin tubes were thoroughly irrigated with $17 \%$ EDTA and sodium hypochlorite, and then washed with distilled water before being autoclaved $^{8}$. The tubes were filled with Angelus ${ }^{\circledR}$
MTA, Sealapex ${ }^{\circledR}$ and a material resulted from the combination of Sealapex ${ }^{\circledR}$ and Angelus ${ }^{\circledR}$ MTA. Of the total, 8 dentin tubes remained empty and were used as controls. The Angelus ${ }^{\circledR}$ MTA and Sealapex ${ }^{\circledR}$ were prepared according to the recommendations of the manufacturers. The combination of Sealapex ${ }^{\circledR}$ and Angelus ${ }^{\circledR}$ MTA was achieved by mixing a portion of MTA to Sealapex until obtaining a putty-like consistence (0.15 g Sealapex/0.5 g MTA), which allowed the improvement of its insertion into the root end cavities.

\section{Protocol in histopathologic study}

The animals were shaved under xylazine (10 $\mathrm{mg} / \mathrm{kg}$ ) and ketamine $(25 \mathrm{mg} / \mathrm{kg})$ anesthesia and disinfected with $5 \%$ iodine solution. The shaved backs received a $2 \mathrm{~cm}$ wide incision in a head-to-tail orientation with the use of a number 15 BP blade. The skin was reflected in order to create two pockets on each side of the incision. The implantation materials were inserted into the spaces created with blunt dissection immediately after the preparation and the skin was closed with $3 / 0$ silk suture.

The evaluations were done at 7 and 30 days after surgical implantation. At the time, the tubes and surrounding tissues were removed and fixed in 10\% buffered formalin. The blocks containing dentin tube were embedded in a mixture of paraffin (95\%) and carnauba wax $(5 \%)^{5}$. The sectioning was serially performed at $10 \mu \mathrm{m}$ intervals with the use of a hard-tissue microtome. The sections were obtained one by one, always after the application of paraffin wax on the sample surface. This layer of paraffin wax holds the sections flat and enables easier fitting onto the heated glass slide with albumen. Then, the sections were either stained according to the Von Kossa technique, or remained without staining in order to be observed under polarized light.

Reactions in the tissue in contact with the material on the open tube end were scored as 0 , none or few inflammatory cells and no reaction; 1 , less than 25 cells and mild reaction; 2, between 25-125 cells and moderate reaction; and 3, 125 and more cells and severe reaction. Fibrous capsules were considered to be thin when thickness was $<150 \mu \mathrm{m}$ and thick at $>150 \mu \mathrm{m}$. Necrosis and calcification were recorded as present or absent. An average of the number of cells for each group was obtained from 10 separate areas. The observer was blinded to treatment allocation. Results were analyzed statistically by ANOVA and Kruskal Wallis tests at $5 \%$ significance level.

\section{In vitro tests \\ Cell culture}

L929 mouse fibroblasts were grown in Dulbecco's modified Eagle's medium (DMEM) supplemented with $10 \%$ fetal bovine serum (GIBCO BRL, 
Gaithersburg, MD, USA) streptomycin $(50 \mathrm{~g} / \mathrm{mL})$, and $1 \%$ antibiotic/antimycotic cocktail (300 units/ $\mathrm{mL}$ penicillin, $300 \mu \mathrm{g} / \mathrm{mL}$ streptomycin, $5 \mu \mathrm{g} / \mathrm{mL}$ amphotericin B) (GIBCO BRL, Gaithersburg, MD, USA) under standard cell culture conditions $\left(37^{\circ} \mathrm{C}\right.$, $100 \%$ humidity, $95 \%$ air, and $5 \% \mathrm{CO}_{2}$ ).

\section{Cytotoxicity Testing}

L929 fibroblasts were seeded into the 24-well plates $\left(3 \times 10^{4}\right.$ cells $/ 1 \mathrm{~mL}$ medium per well). The cells were incubated for $24 \mathrm{~h}$ in a humidified air atmosphere of $5 \% \mathrm{CO}_{2}$ at $37^{\circ} \mathrm{C}$. The test materials were placed in clear, unfilled polyethylene tubes $(1.1 \mathrm{~mm}$ inner diameter $\times 10 \mathrm{~mm}$ length (BARD, C.R., Bard Ireland LTDA, Galway, Ireland), and inserted in the fibroblast culture. Six wells were used for each material and an empty tube was used as control. The exposures of cell cultures were stopped by the discarding of the exposure media after $24 \mathrm{~h}$. Viable cells were stained with formazan dye (3-[4,5-dimethylthiazol-2-yl]-2,5-diphenyl tetrazolium bromide) (MTT) (Sigma Chemical Co, St Louis, MO, USA). MTT was dissolved in PBS at $5 \mathrm{mg} / \mathrm{mL}$ and filtered in order to sterilize and remove a small amount of insoluble residue. At the times indicated below, stock MTT solution (20 $\mu \mathrm{L}$ per $180 \mu \mathrm{L}$ medium) was added to all wells of an assay, and plates were incubated at $37^{\circ} \mathrm{C}$ for 4 $\mathrm{h}$. The medium was then removed by inverting the plate and dumping $200 \mu \mathrm{L}$ of isopropylic alcohol, which was added to the wells and mixed during $30 \mathrm{~min}$ to dissolve the dark blue crystals. The blue solution was transferred to a 96-well plate and the absorbance was read in the micro plate reader at $570 \mathrm{~nm}$ wavelength. Data were analyzed statistically by ANOVA and Bonferroni correction. Statistically significant differences were considered if $p<0.05$.

\section{Cytokine assay}

For cytokine assay, the tested materials were inserted into the wells of 24-well flat bottom plates (Corning Incorporated, Corning, NY, USA), and condensed to disks that were approximately $1 \mathrm{~mm}$ thick and with the same diameter of the wells. The materials were allowed to set for 2 weeks in cell culture medium at $37^{\circ} \mathrm{C}$ and $100 \%$. The medium was changed every day during this time. L929 fibroblasts were seeded into the wells $\left(10^{6}\right.$ cells $/ 1$ $\mathrm{mL}$ medium per well) with the material disks in the bottom. The plates were incubated for $24 \mathrm{~h}$. After incubation, culture media were collected and analyzed for IL- $1 \beta$ and IL- 6 content by ELISA (R\&D Systems, Inc., Minneapolis, MN, USA). Cells cultured without tested material served as negative controls. Data were analyzed statistically by ANOVA and Bonferroni correction. Statistical differences were considered significant if $p<0.05$.

\section{RESULTS}

\section{Histopathologic study}

In the control group, the implanted tubes were surrounded by a layer of exudate with neutrophils at the $7^{\text {th }}$ day. Over this area, there were young fibroblasts and chronic inflammatory cells in a moderate amount.

Thirty days after implantation, in the control group, the samples showed ingrown connective tissue with mild chronic inflammatory cells filling the tube space. Outside, the tubes were surrounded by a thin fibrous capsule exhibiting a mild chronic inflammatory reaction (Figure 1 ).

In the experimental groups, the results observed with the implantation of the tubes filled by MTA, Sealapex or the combination of Sealapex and MTA (Sealapex Plus) were similar at 7 and 30 days.

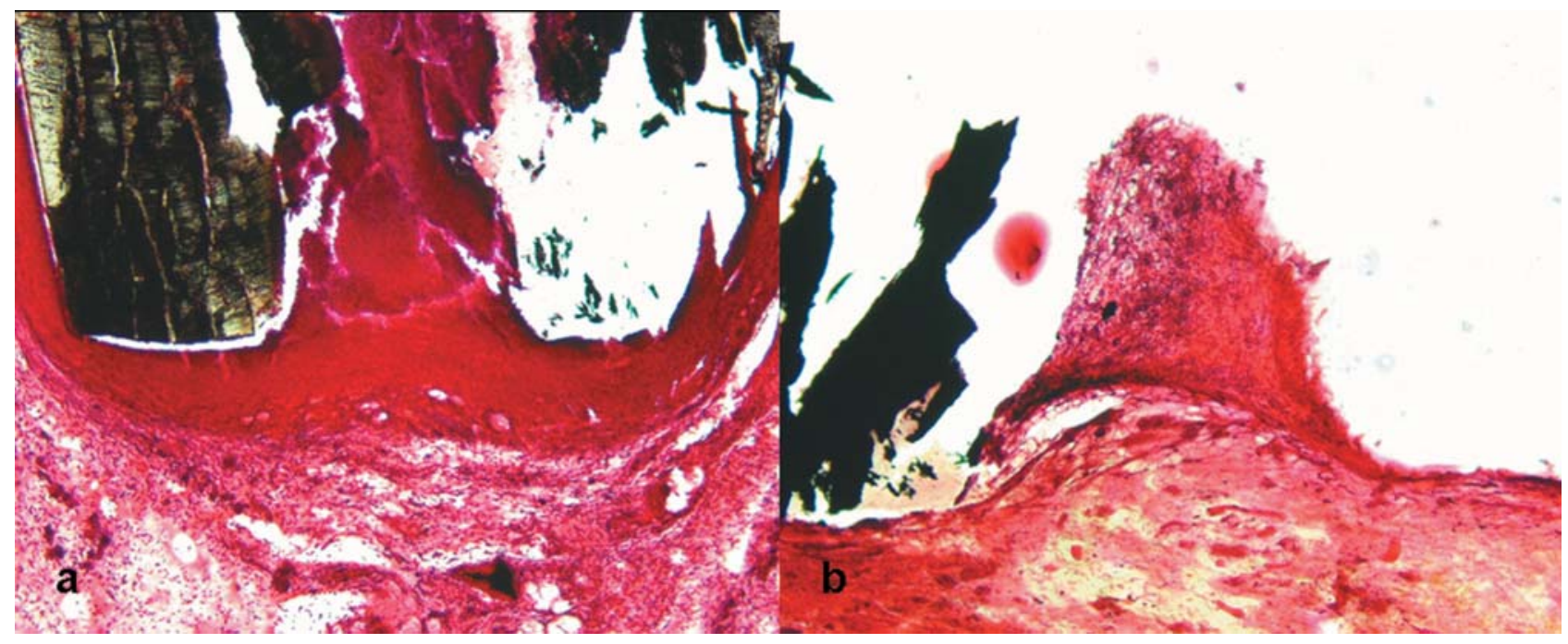

Figure 1- (Control group) (a) 7 days. Von Kossa positive granulations were not observed near the tube opening (7 days, VK, 100x). (b) Von Kossa positive granulations were not observed near the tube opening (30 days, VK, 100x) 


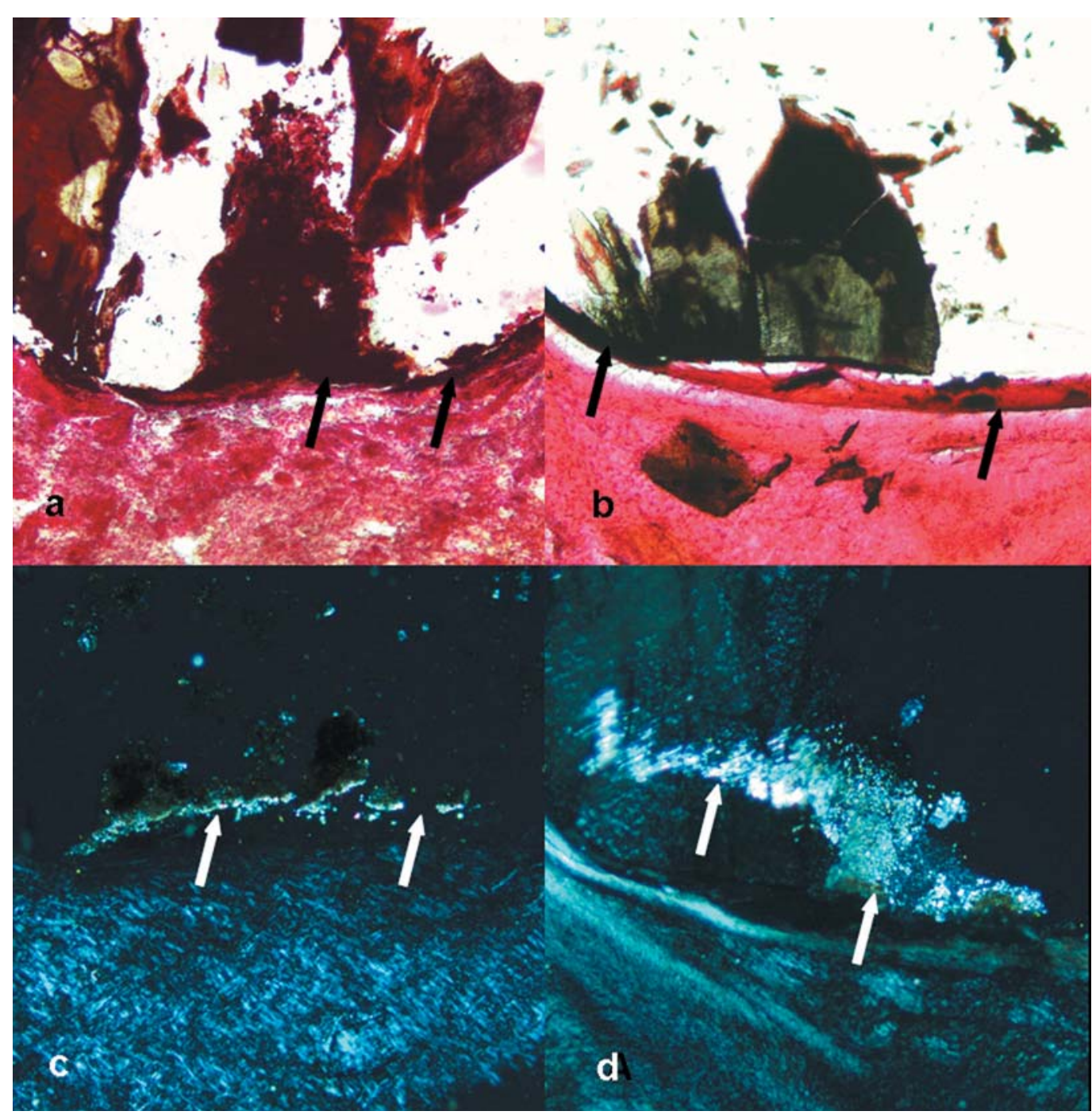

Figure 2- (MTA) (a) Observe Von Kossa-positive irregular tissue (arrows) located near the material (7 days, VK, 50x). (b). Observe Von Kossa-positive irregular tissue (arrows) located near the tube opening (30 days, VK, 50x). (c) Note numerous granulations (arrows), birefringent to polarized light (7 days, polarized light, 50x). (d). Note numerous granulations (arrows), birefringent to polarized light (30 days, polarized light, 50x)

At the $7^{\text {th }}$ day, all materials exhibited a moderate chronic inflammatory reaction that became mild at the $30^{\text {th }}$ day, similar to that observed in the control group. The non-demineralized sections exhibited birefringent granulations to polarized light (Figures 2C, 2D, 3C and 3D) as well as extensive and irregular areas which were highly positive to Von Kossa staining, next to the birefringent granules (Figures 2A, 2B, 3A and 3B).

\section{Comparison among the groups}

The data were compared in each period of time and are presented in the Table 1.

At day 7 , there was no statistically significant difference among the scores of the different groups (mean score of 2). At day 30, there was no statistically significant difference among the scores of the different groups (mean score of 1 ).

\section{In vitro tests}

For the MTT assay ( $24 \mathrm{~h}$ ), no statistically difference was found $(p<0.05)$ between the experimental material $s$ and the control group. Sealapex, Sealapex Plus and MTA did not inhibit the cell viability. These results were expressed as means of the absorbance $\left(A_{570 \mathrm{~nm}}\right)$ of each material and control group (Figure 4).

The mean concentrations of IL- 6 for the different groups are shown in Figure 5. The ELISA revealed that the mean levels of IL- 6 were raised when the cells were grown in the presence of MTA, Sealapex and Sealapex Plus at $24 \mathrm{~h}$. There was not statistically significant difference $(p<0.05)$ between the experimental materials and the control group.

The mean concentrations of IL-1 $\beta$ for the different groups are shown in Figure 6. The ELISA assays revealed that the mean levels of $\mathrm{IL}-1 \beta$ were slightly raised when the cells were grown in the presence of MTA and Sealapex Plus at $24 \mathrm{~h}$. 


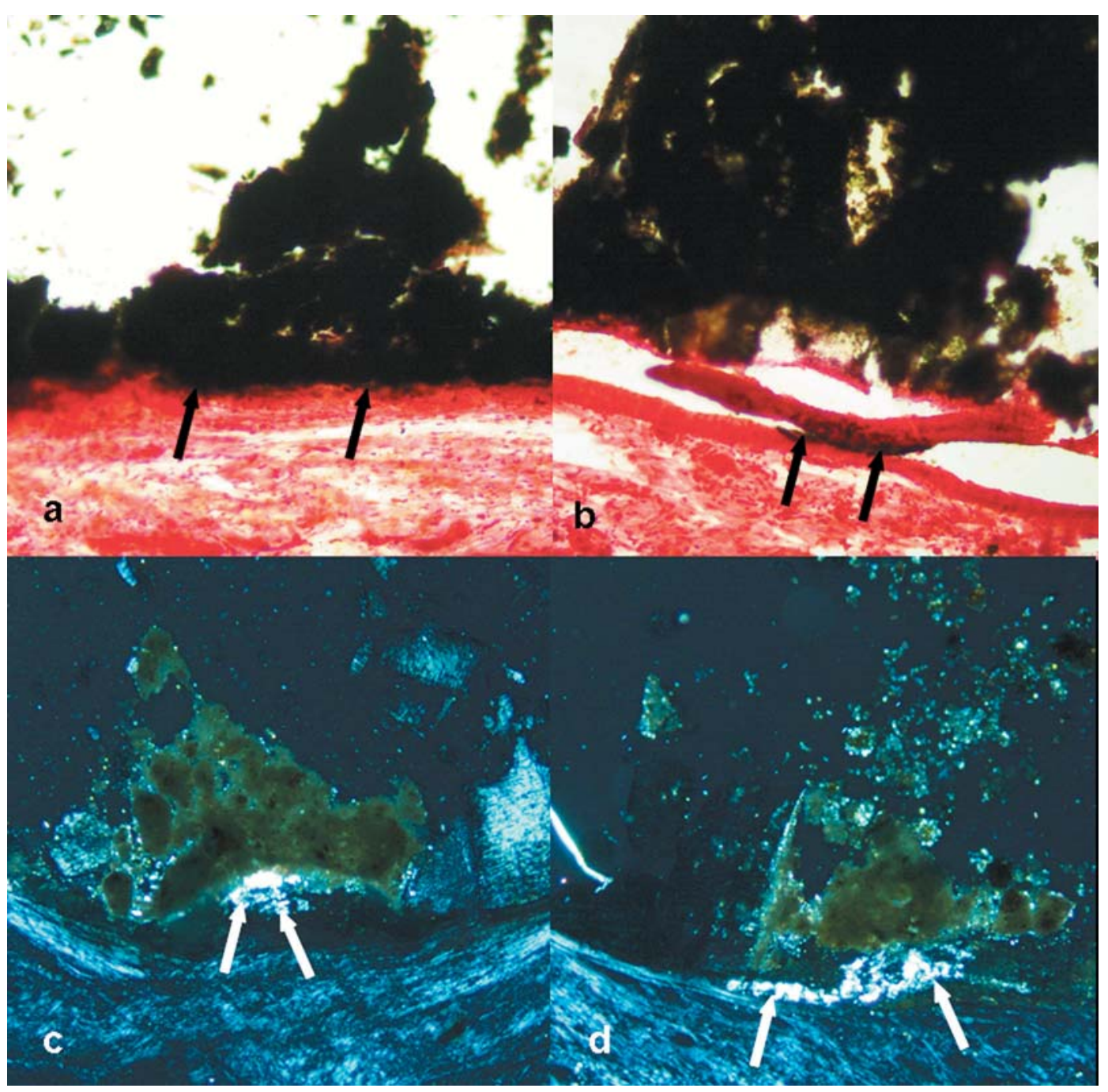

Figure 3- (Sealapex Plus) (a) Observe Von Kossa-positive irregular tissue (arrows) located near the material (7 days, VK, 100x). (b) Observe Von Kossa-positive irregular tissue (arrows) located near the tube opening (30 days, VK, 100x). (c) Note numerous granulations (arrows), birefringent to polarized light (7 days, polarized light, 100x). (d) Note numerous granulations (arrows), birefringent to polarized light (30 days, polarized light, 100x)

Table 1- Percentage of samples in each group categorized according to the inflammatory score, presence of necrosis and thickness of fibrous capsule

\begin{tabular}{|c|c|c|c|c|c|c|c|}
\hline \multirow[t]{2}{*}{ MATERIAL } & \multicolumn{7}{|c|}{ SCORE } \\
\hline & 0 & 1 & 2 & 3 & calcification & necrosis & capsule \\
\hline \multicolumn{8}{|l|}{7 days } \\
\hline Sealapex & 0 & 0 & 100 & 0 & 100 & present & thick \\
\hline MTA & 0 & 0 & 100 & 0 & 100 & present & thick \\
\hline Sealapex Plus & 0 & 0 & 100 & 0 & 100 & present & thick \\
\hline Control & 0 & 0 & 100 & 0 & 0 & absent & thick \\
\hline \multicolumn{8}{|l|}{30 days } \\
\hline Sealapex & 0 & 100 & & 0 & 100 & absent & thick \\
\hline MTA & 0 & 100 & 0 & 0 & 100 & absent & thin \\
\hline Sealapex Plus & 0 & 100 & 0 & 0 & 90 & absent & thin \\
\hline Control & 0 & 100 & 0 & 0 & 0 & absent & thin \\
\hline
\end{tabular}




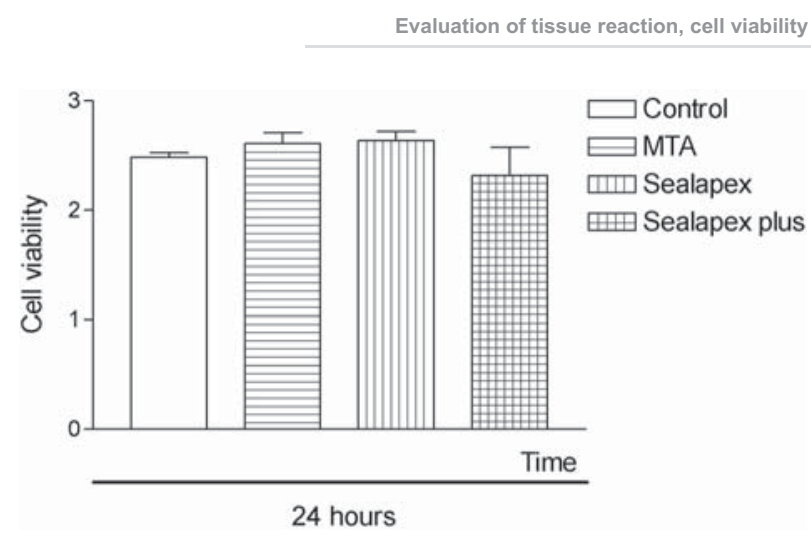

Figure 4- Viability of fibroblasts in the presence of different materials at $24 \mathrm{~h}$. It was not found statistically significant difference $(p<0.05)$ between the experimental materials and the control group. These results were expressed as means of the absorbance (A570 nm) \pm standard deviation of each material and the control group

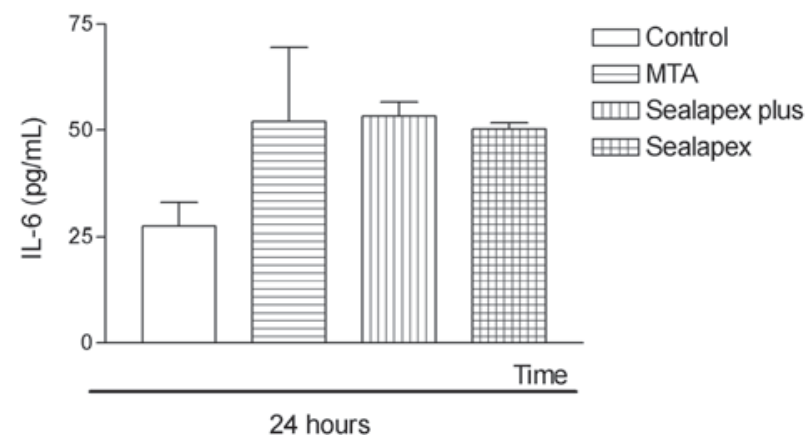

Figure 5 - Mean expression of IL-6 from fibroblasts cells in the presence of different materials at $24 \mathrm{~h}$. Mean levels of IL-6 were raised when the cells were grown in the presence of the materials. There was not statistically significant difference $(p<0.05)$ between the experimental materials and the control group

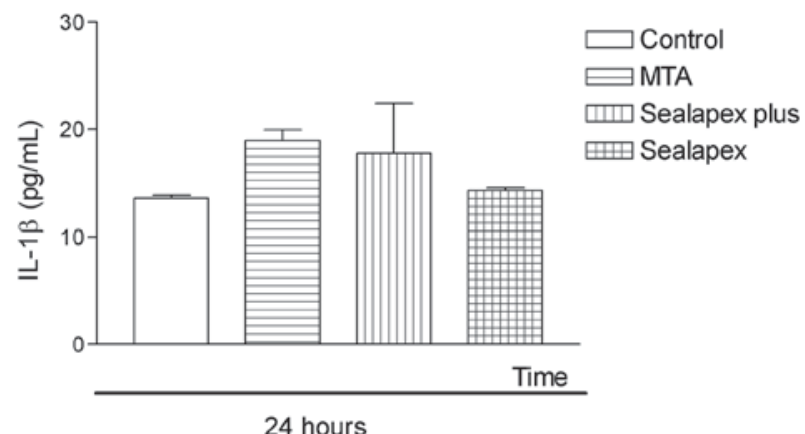

Figure 6 - Mean expression of IL-1 $\beta$ from fibroblasts cells in the presence of different materials at $24 \mathrm{~h}$. Mean levels of IL-1 $\beta$ were slightly raised when the cells were grown in the presence of MTA and Sealapex Plus at $24 \mathrm{~h}$. Moreover, the cells did not induce IL-1 $1 \beta$ production in the presence of Sealapex. There was not statistically significant difference $(p<0.05)$ between the experimental materials and the control group
Moreover, the cells did not induce IL-1 $1 \beta$ production in the presence of Sealapex. In spite of the slight raise of IL- $1 \beta$ concentration in MTA and Sealapex Plus groups, there was no statistically significant difference $(p<0.05)$ between the experimental materials and the control group.

\section{DISCUSSION}

The dentin tubes for subcutaneous implantation were used according to Holland, et al. ${ }^{9}$ (1999). Empty tubes from control groups promoted few or no reactions in subcutaneous tissue and produced normal repair tissues, similar to results reported in the literature ${ }^{8,9}$.

The present results with MTA were similar to those previously described when dentin tubes filled with this material were implanted in subcutaneous tissue of rats $^{8,9}$. It is known that MTA has no calcium hydroxide in its formulation ${ }^{4}$. However, mixing the powder with water results in a structure that contains basically calcium oxide and calcium phosphate ${ }^{25}$. The calcium oxide reacted with tissue fluids to form calcium hydroxide. The birefringent granulations observed next to MTA and into the dentin walls tubules are probably calcite crystals originated from the reaction of the calcium from the material with carbon dioxide from the connective tissue 9 . The deposition of calcite crystals seems to be very important to the mechanism of action of calcium hydroxide formed from the mixture of MTA with water. Seux, et al. ${ }^{20}$ (1991) reported a rich extra cellular network of fibronectin in close contact with these crystals on incubation in a culture medium without cells. They reported that fibronectin first came from the culture medium and later from the cells. The authors concluded that their findings strongly supported the role of calcite crystals and fibronectin as an initiating step in the formation of a hard tissue barrier. In our study, we observed a von Kossa-positive tissue barrier next to these crystals, like the hard tissue deposition in direct contact with MTA, as described in other papers ${ }^{9}$. This hard tissue is very irregular in subcutaneous tissue ${ }^{25}$, but similar to dentin in pulp tissue ${ }^{2,25}$ and periapical tissues ${ }^{2,27}$.

In this experiment, the same structures found with MTA were observed with the Sealapex Plus. The birefringent granulations and the Von Kossa-positive tissue structures were present in the same amount. Sealapex is a calcium hydroxide based sealer, and it was possible to observe similar biological characteristics and action mechanism with calcium hydroxide and MTA ${ }^{7}$. The high solubility of Sealapex enhances the physicochemical and biological features and the releasing of more calcium and hydroxyl ions may lead it to induce the root apex mineralization ${ }^{6}$. However, it would be possible that 
the combination of Sealapex with MTA would alter the solubility and the release of calcium ions from the material, but the results reported in this paper show that this hypothesis was null once birefringent structures to polarized light and Von Kossa-positive structures continued to be observed encouraging more studies and its future use.

In vitro tests such as cell culture enable experimental factors and variables to be controlled, which is often a significant problem when performing in vivo experiments ${ }^{21}$. The mouse fibroblasts cell line (L929), which has also been used in previous cell viability studies ${ }^{17,26}$, was chosen in this experimental model.

In this study, cell viability was determined by MTT assay based on the ability of mitochondrial dehydrogenase enzymes in living cells to convert the yellow water-soluble tetrazolium salt MTT into dark blue formazan crystals. The advantages of this method are its simplicity, rapidity and precision. In addition, it does not require radioisotopes ${ }^{11}$. Statistical analyses of the data of the MTT assay showed no significant differences among the three cements in $24 \mathrm{~h}$. However, longer periods of observation could be performed to evaluate the effects of the sealers on the cells along the time once the cytotoxicity can be altered with the time.

Although the experimental conditions in this study differed from those used in others studies, our results agree with previous studies that showed that MTA was not cytotoxic ${ }^{17,25}$. Torabinejad, et al. ${ }^{25}$ (1995), using agar overlay assay in L-929 mouse, tested samples of MTA, amalgam, Super-EBA and Intermediate Restorative Material (IRM), and found that freshly mixed and set amalgam were significantly less toxic than MTA, Super EBA, and IRM. However, when radiochromium methods were used, the degree of cytotoxicity of fresh and set materials showed that MTA was less toxic than the rest of the materials tested.

Sealapex was not cytotoxic when compared to the control group. Previous study found that calcium hydroxide-based sealers were cultured with human fibroblasts for three weeks, showing a cytotoxic reaction at the beginning and an almost complete recovering of the Sealapex by fibroblasts between the $5^{\text {th }}$ and $9^{\text {th }}$ day of culturing, and remained this way during the rest of the testing period ${ }^{3}$. The results of that study disagree with other previous studies that proved Sealapex to be cytotoxic ${ }^{10,11,13}$.

The use of sealers based on calcium hydroxide has been proposed for the permanent obturation of the root canal system. Sealapex is primarily made of calcium hydroxide, and it demonstrates only slight toxicity in the fresh state. However, it exhibited increasing toxicity when set to confirm the results of previous studies that reported considerable leakage of cytotoxic substances from the disintegrating sealer ${ }^{13}$. This apparent instability in an aqueous environment might enhance the release of substances from set Sealape ${ }^{11}$.

The combination between Sealapex and MTA (Sealapex Plus) was not cytotoxic in the present investigation. It is possible to assume that the combination of Sealapex and MTA, which have adequate behavior in cell culture ${ }^{17,25}$ maintained the qualities of the isolated materials on cell viability. Although this experimental combination apparently presents positive characteristics, other studies and methodologies are necessary to confirm the benefit of this material.

The synthesis of cytokines is very complex, and their expression and effects are governed by many factors that include other cells and mediators ${ }^{22}$. Previous studies have shown that MTA-stimulated osteoblasts produce IL- $1 \beta^{22}$. In this study, there was a slight production of IL- $1 \beta$ by fibroblasts stimulated by MTA and Sealapex Plus; however, it was not statically significant when compared with the control. Moreover, we also did not find IL-1 $\beta$ release related to Sealapex. It is possible that IL-1 $\beta$ expression requires a greater stimulus than other cytokines, and because of the reduced amount of substrate in this study, the product was not enough. Due to the inflammatory response of IL-1, which acts as an uncoupling agent between bone resorption and formation ${ }^{10}$, IL-1 production would be depressed with very biocompatible materials ${ }^{15}$.

In this study, there was also an investigation on the effect of root-end filling materials on IL-6 release. Other cell types like osteoblast cells, when in the presence of MTA, expressed high concentrations of IL- $6^{15}$. The expression of IL- 6 in the presence of all materials suggests that not only they are biocompatible, but they also may promote healing with stimulation of bone turnover, due to the stimulation of osteoclast formation and recruitment by IL-6 ${ }^{30}$.

\section{CONSLUSION}

The obtained results and the mechanism of action of Sealapex Plus were similar to those reported for MTA. Sealapex Plus was not cytotoxic at $24 \mathrm{~h}$. In the presence of Sealapex Plus L929 expressed high concentrations of IL- 6 and slight concentrations of IL- $1 \beta$. The results also suggest that Sealapex Plus is biocompatible and stimulates the mineralization of the tissue, but further studies are necessary to corroborate the present findings. 


\section{REFERENCES}

1- Bernabé PF, Cintra LT, Gomes-Filho JE, Saito CT, Bernabé DG, Otoboni JA, et al. Evaluación in vitro de la capacidad selladora marginal de materiales retroobturadores: estudio del cemento Sealapex adicionado con MTA. Med Oral. 2006;8:61-7.

2- Bernabé PF, Holland R, Morandi R, Souza V, Nery MJ, Otoboni Filho JA, et al. Comparative study of MTA and other materials in retrofilling of pulpless dogs' teeth. Braz Dent J. 2005; 16:149-55. 3- Briseño B, Willershausen B, Sonnabend E. The effect of root canal filling materials on gingival fibroblast cultures. Schweiz Monatsschr Zahnmed. 1991;101:294-8.

4- Byström A, Claesson R, Sundqvist G. The antibacterial effect of camphorated paramonochlorophenol, camphorated phenol and calcium hydroxide in the treatment of infected root canals. Endod Dent Traumatol. 1985;1:170-5.

5- Holland R, Mello W, Nery MJ, Bernabé PF, Souza V. Reaction of human periapical tissue to pulp extirpation and immediate root canal filling with calcium hydroxide. J Endod. 1977;3:63-7.

6- Holland R, Souza V, Murata SS, Nery MJ, Bernabé PF, Otobon Filho JA, et al. Healing process of dog dental pulp after pulpotomy and pulp covering with mineral trioxide aggregate or Portland cement. Braz Dent J. 2001;12:109-13.

7- Holland R, Souza V, Nery MJ, Bernabé FE, Otoboni JA Filho, Dezan $\mathrm{E} J \mathrm{r}$, et al. Calcium salts deposition in rat connective tissue after the implantation of calcium hydroxide-containing sealers. J Endod. 2002;28:173-6.

8- Holland R, Souza V, Nery MJ, Otoboni JA Filho, Bernabé PF, Dezan E Jr. Reaction of rat connective tissue to implanted dentin tubes filled with mineral trioxide aggregate or calcium hydroxide. ] Endod. 1999;25:161-6.

9- Holland R, Souza V. Ability of a new calcium hydroxide root canal filling material to induce hard tissue formation. J Endod. 1985; 11:535-43.

10- Huang TH, Ding SJ, Hsu TZ, Lee ZD, Kao CT. Root canal sealers induce cytotoxicity and necrosis. J Mater Sci Mater Med. 2004; 15:767-71.

11- Huang FM, Tai KW, Chou MY, Chang YC. Cytotoxicity of resin-, zinc oxide-eugenol-, and calcium hydroxide-based root canal sealers on human periodontal ligament cells and permanent V79 cells. Int Endod J. 2002;35:153-8.

12- Lee SJ, Monsef M, Torabinejad M. Sealing ability of a mineral trioxide aggregate for repair of lateral root perforations. J Endod. 1993;19:541-4.

13- Leonardo RT, Consolaro A, Carlos IZ, Leonardo MR. Evaluation of cell culture cytotoxicity of five root canal sealers. J Endod. $2000 ; 26: 328-30$.
14- Matt GD, Thorpe JR, Strother JM, McClanahan SB. Comparative study of white and gray mineral trioxide aggregate (MTA) simulating a one- or two-step apical barrier technique. J Endod. 2004;30:876-9.

15- Mitchell PJ, Pitt Ford TR, Torabinejad M, McDonald F. Osteoblast biocompatibility of mineral trioxide aggregate. Biomaterials. 1999;20:167-73.

16- Nakata TT, Bae KS, Baumgartner JC. Perforation repair comparing mineral trioxide aggregate and amalgam using an anaerobic bacterial leakage model. J Endod. 1998;24:184-6.

17- Osorio RM, Hefti A, Vertucci FJ, Shawley AL. Cytotoxicity of endodontic materials.J Endod. 1998;24:91-6.

18- Pitt Ford TR, Torabinejad M, Abedi HR, Bakland LK, Kariyawasam SP. Using mineral trioxide aggregate as a pulpcapping material. J Am Dent Assoc. 1996;127:1491-4.

19- Safavi KE, Nichols FC. Effect of calcium hydroxide on bacterial lipopolysaccharide. J Endod. 1993;19:76-8.

20- Seux D, Couble ML, Hartmann DJ, Gauthier JP, Magloire H. Odontoblast-like cytodifferentiation of human dental pulp cells in vitro in the presence of a calcium hydroxide-containing cement. Arch Oral Biol. 1991;36:117-28.

21- Spångberg L. Biological effects of root canal filling materials. 6 . The inhibitory effect of solubilised root canal filling materials on respiration of HeLa cells. Odontol Tidskr. 1969;77:121-31

22- Stashenko P, Dewhirst FE, Rooney ML, Desjardins LA, Heeley JD. Interleukin-1 beta is a potent inhibitor of bone formation in vitro. J Bone Miner Res. 1987;2:559-65.

23- Tagger M, Tagger E. Periapical reactions to calcium hydroxidecontaining sealers and AH 26 in monkeys. Endod Dent Traumatol. 1989;5:139-46.

24- Torabinejad M, Chivian N. Clinical applications of mineral trioxide aggregate. J Endod. 1999;25:197-205.

25- Torabinejad M, Hong CU, McDonald F, Pitt Ford TR. Physical and chemical properties of a new root-end filling material. J Endod. $1995 ; 21: 349-53$

26- Torabinejad M, Hong CU, Pitt Ford TR, Kettering JD. Cytotoxicity of four root end filling materials. J Endod. 1995;21:489-92.

27- Torabinejad M, Watson TF, Pitt Ford TR. Sealing ability of a mineral trioxide aggregate when used as a root end filling material. J Endod. 1993;19:591-5.

28- Tronstad L. Root resorption - etiology, terminology and clinical manifestations. Endod Dent Traumatol. 1988;4:241-52.

29- Tronstad L, Andreasen JO, Hasselgren G, Kristerson L, Riis I. $\mathrm{pH}$ changes in dental tissues after root canal filling with calcium hydroxide. J Endod. 1981;7:17-21.

30- Wong GG, Witek-Giannotti J, Hewick RM, Clark SC, Ogawa M. Interleukin 6: identification as a hematopoietic colony-stimulating factor. Behring Inst Mitt. 1988;(83):40-7. 